\title{
A Case Study: Polychlorinated Dibenzo-p-dioxins, Polyclorinated Dibenzofurans, Polychlorinated biphenyls, and Polybrominated diphenyl ethers in the bone marrow and lymph nodes of adult reindeer (Rangifer tarandustarandus $L_{\text {.) }}$ hind in Finland
}

\author{
Anniina Holma-Suutari ${ }^{1 *}$ and Sauli Laaksonen ${ }^{2}$ \\ ${ }^{1}$ Department of Biology, University of Oulu, Finland \\ ${ }^{2}$ University of Helsinki, Finland
}

Received: September 26, 2017; Published: October 06, 2017

*Corresponding author: Anniina Holma - Suutari, Department of Biology, University of Oulu, P. O. Box 3000, 90014, Oulu, Finland,

\section{Introduction}

It is typical for POPs that they are transported long distances from source to sink areas. Reindeer (Rangifer tarandustarandus L.) is considered to be one of the most important indicator species for environmental toxic contaminants because it uses natural pastures and is exposing continuously to environmental contaminant deposition [1]. The immune system is one of the most sensitive targets for the toxic effects of TCDD and structurally similar POPs [2]. The Aryl Hydrocarbon Receptor (AhR) is important factor in immunotoxic mechanism of POPs. Many pathways of cellular activation, proliferation, and survival have the potential to be influenced by AhR activation, leading to alterations in the function of the immune system $[3,4]$. We report PCDD/Fs, PCBs, and PBDEs content of tissues relating to immune system and hematopoiesis, lymph nodes and bone marrow, of adult reindeer hind. The congener specific profiles are explored and compared between these two tissue types.

\section{Material and Methods}

An adult reindeer hind (age $>10$ years) from Finnish reindeer management area (southern site) was slaughtered and lymph nodes and bone marrow samples were immediately extracted for analysis. High resolution gas chromatography - high resolution mass spectrometry (HRGC/HRMS) was used to analyses of POPs. Analyzes were performed at the National Institute for Health and Welfare (THL), in the Unit of Chemical Exposure, in Finland. The Unit is a FINAS accredited testing laboratory (No T077) according to EN ISO/IEC 17025 requirements.

\section{Results}

It is seen that WHO-PCDD/F-TEQ concentrations are slightly higher in lymph node sample than in bone marrow sample. Considering WHO-PCB-TEQs an opposite observation is seen; WHO-PCB-TEQ in bone marrow is higher than in lymph nodes. This is applying also to indicator-PCBs, which concentration $3.95 \mathrm{ng} / \mathrm{g}$ fat in lymph nodes is $27 \%$ lower than concentration $5.40 \mathrm{ng} / \mathrm{g}$ fat) in bone marrow. When examining PBDE concentrations there is clear difference between the samples. PBDE concentration in bone marrow ( $0.18 \mathrm{ng} / \mathrm{g}$ fat, lower bound) is $99 \%$ lower than in lymph nodes (28.5 ng/g fat). A contribution of BDE-209 is wide; it almost covers the whole total concentration. In lymph nodes the congener most contributing the total WHO-PCDD/F-TEQ is 2,3,7,8-TCDF, when in bone marrow the corresponding congener is $2,3,4,7,8-\mathrm{PeCDF}$. Other discernible $\mathrm{PCDD} / \mathrm{F}$ congeners in the samples are 2,3,7,8-TCDD, 1,2,3,7,8-PeCDD, 1,2,3,4,7,8-HxCDD, 1,2,3,6,7,8-HxCDD, 1,2,3,4,6,7,8-HpCDD, 1,2,3,4,7,8-HxCDF, $1,2,3,6,7,8-\mathrm{HxCDF}$, and $2,3,4,6,7,8-\mathrm{HxCDF}$. Considering the coplanar non-ortho-PCB congeners in the lymph nodes the most frequently seen are PCB-126 and PCB-77. However, in bone marrow sample PCB-77 is thin, whereas PCB-126 is contributing strongly to WHO-PCB-TEQ. Comparing the PBDE congener profiles between the lymph node and bone marrow samples there is seen a clear difference. In bone marrow sample BDE-153 and BDE-209 are the most heavily contributing congeners their concentrations being quite equal (0.088 ng/g fat for BDE-153 and $0.092 \mathrm{ng} / \mathrm{g}$ fat for BDE209, respectively). The total PBDE sum of bone marrow sample is 
low, only $0.18 \mathrm{ng} / \mathrm{g}$ fat, lower bound ( $0.29 \mathrm{ng} / \mathrm{g}$ fat, upper bound). In lymph node sample, there is seen that almost all contribution to total sum of PBDEs is coming from BDE-209. Its concentration is much higher than any other PBDE congener, namely $28 \mathrm{ng} / \mathrm{g}$ fat (Total PBDE sum $28.5 \mathrm{ng} / \mathrm{g}$ fat, lower bound, $28.6 \mathrm{ng} / \mathrm{g}$ fat, upper bound).

\section{Conclusion}

Different congener profiles of PCDD/Fs, PCBs, and PBDEs were found in adult reindeer hind lymph nodes and bone marrow. These two tissue types represent different fat contents (In the lymph node sample the fat percentage was 10.4, while it was 33.0 in bone marrow sample) and it is seen that at least all POP congeners do not distribute according to fat $\%$. The most visible indication of this is accumulation of BDE-209 in reindeer lymph nodes (lipid adjusted concentration $28 \mathrm{ng} / \mathrm{g}$ fat of total concentration $28.5 \mathrm{ng} / \mathrm{g}$ fat, lower bound). As knowing the POP toxicity can disturb immunological functions on mammals, and our study was based only on one animal, it is essential to emphasize the importance of further researches of POP induced reduction of immuno-competence on reindeer. It is in question of species culturally and economically important for arctic and sub-arctic people.

\section{References}

1. Holma Suutari A, Ruokojärvi P, Komarov AA, Makarov DA, Ovcharenko VV, et al. (2016) Biomonitoring of selected persistent organic pollutants (PCDD/Fs, PCBs and PBDEs) in Finnish and Russian terrestrial and aquatic animal species. Environ Sci Eur 28(1): 5.

2. Corsini E, Luebke RW, Germole DR, De Witt JC (2014) Perfluorinated compounds: Emerging POPs with potential immunotoxicity. Toxicology Letters 230(2): 263-270.

3. Kerkvliet N (2003) Immunotoxicology of Dioxins and Related Chemicals. Dioxins and Health, Second Edition, Edited by Arnold Schecter and Thomas A. Gasiewicz ISBN 0-471-43355-1 62003 John Wiley \& Sons, Inc.

4. Holma Suutari A (2014) Harmful agents (PCDD/Fs, PCBs, and PBDEs) in Finnish reindeer (Rangifer tarandustarandus) and moose (Alcesalces). Academic dissertation. University of Oulu.

\begin{tabular}{|l} 
BIOMEDICAL \\
RESEARCHES
\end{tabular}$\quad \begin{aligned} & \text { Assets of Publishing with us } \\
& \text { - Global archiving of articles }\end{aligned}$

